\title{
Knowledge and Attitudes of Mothers on the Behavior of Wearing Masks to Children Towards COVID -19 Prevention in Meri Mojokerto East Java
}

\author{
Asih Media Yuniarti ${ }^{1}$ Dwi Helynarti Syurandhari ${ }^{2}$ Mukhammad Himawan Saputra, ${ }^{3, *}$ \\ Rian Fitroh $\mathrm{Huda}^{4}$
}

1,2,3,4 Department of Public Health, STIKES Majapahit Mojokerto, Indonesia

*Corresponding author. Email: mhimawansaputra@gmail.com

\begin{abstract}
Coronaviruses are part of the virus family that causes illnesses ranging from the flu to more severe illnesses such as Middle East Respiratory Syndrome and Severe Acute Respiratory Syndrome. COVID-19 is a new type of disease that was discovered in 2019 and has never been identified as affecting humans before. The purpose of this research was to analyze the relationship between knowledge and attitudes of mothers with the behavior of using masks in children in the prevention of COVID. This research was a correlational analytic study. The population in this study was 37 respondents, taken as a sample using a simple random sampling technique as many as 33 respondents. Data was analyzed by the Chi-square test \& Spearman Rank test. Based on the results of the Spearman rank test on the knowledge and attitude variable, the Asymp value is obtained. Sig is $0,000<\alpha(0.05)$, which means that there is a relationship between maternal knowledge and attitude with the behavior of using masks in children in efforts to prevent COVID-19. The mother's behavior in using masks on children is determined by knowledge and attitudes. The information that is absorbed by mothers regarding the use of masks to prevent direct transmission of the coronavirus will increase the knowledge and attitudes of mothers, and the increasing knowledge and attitudes of mothers will increase the behavior of mothers in using masks to children
\end{abstract}

Keywords: stunting, diet culture, health services, fast food.

\section{INTRODUCTION}

The problem of stunting is an issue that harms nutritional problems in Indonesia because it affects the physical and functional nature of the child's body and increases Covid-19 is a disease caused by the coronavirus. Coronaviruses $(\mathrm{CoV})$ are part of a family of viruses that cause illnesses ranging from the flu to more severe illnesses such as Middle East Respiratory Syndrome (MERS-CoV) and Severe Acute Respiratory Syndrome (SARS-CoV). The disease caused by the coronavirus, otherwise known as COVID-19, is a new strain that was discovered in 2019 and has never been identified in humans before. [1][2]

The case of the coronavirus appeared and attacked humans for the first time in the province of Wuhan, China. Initially, it was suspected that it was pneumonia, with flu-like symptoms in general. Symptoms include cough, fever, fatigue, shortness of breath, and no appetite. However, unlike influenza, the coronavirus can develop rapidly, resulting in more severe infections and organ failure, and death. This emergency condition mainly occurs in patients with previous health problems[3]

On December 31, 2019, the WHO China Country Office reported a case of pneumonia of unknown etiology in Wuhan City, Hubei Province, China. On January 7, 2020, China identified pneumonia of unknown etiology as a new type of coronavirus (coronavirus disease, COVID-19). On January 30, 2020 WHO has declared it a Public Health Emergency of International Concern (KKMMD/PHEIC). The increase in the number of COVID-19 cases is happening quite quickly and has spread between countries[1][3]

The percentage of Covid-19 cases in Indonesian children, based on data from the Ministry of Health, is 7.5 percent overall. This is relatively high compared to other countries, which is around 1 to 5 percent, with the 
death rate also quite high compared to other countries when viewed by age. In other countries, it is almost undetectable, while in Indonesia it is 1.8 percent or 3.8 percent by age group [4]

Knowledge about the Covid-19 disease is very important so as not to cause an increase in the number of Covid-19 cases. Knowledge of Covid-19 patients can be interpreted as the result of knowing from the patient about their illness, understanding the disease, how to prevent it, treat it and its complications. [5]

Knowledge of Covid-19 prevention with compliance with the use of masks has an important role in anticipating repeated events. The public must recognize, study and understand all aspects of the Covid-19 disease including signs and symptoms, causes, triggers, and management. Knowledge has a close relationship with the decisions that will be taken because with knowledge a person has a basis for making choices and the mother plays an important role of the behavior carried out by her child.[3]

\section{MATERIAL AND METHOD}

The design used in this research is quantitative with an analytic observational design. The approach used is cross-sectional. The population in this study were all mothers who have elementary school-aged children in the RW 1 Meri Village, Mojokerto City as many as 37 people. The sample size in this study was33 respondents, where the sample was taken by simple random sampling. The analysis used to determine the relationship between the independent variable and the dependent variable was carried out by statistical tests using the Spearmann rank test.

\section{RESULT}

Based on the results of the study, it was found that most children did not have the opportunity to eat a variety of foods (44\%). Most children are also free to eat what they want, nutritious or not $(72 \%)$. Children are not able to choose what type of food is nutritious or not, they will choose the type of food that is attractive in color and tastes good. It is the role of parents to choose nutritious food for their children by not letting them choose their own food. The number of children who did not receive exclusive breastfeeding was $39.4 \%$. this is one of the causes of many stunting cases in this region.

\subsection{Respondents' Knowledge about the Wearing a Masks}

Table 1. Distribution of Respondents' Knowledge about the Wearing a Masks

\begin{tabular}{|l|l|c|c|}
\hline No & Knowledge & f & \% \\
\hline 1 & Good & 19 & 57 \\
2 & Sufficient & 9 & 27 \\
3 & Insufficient & 5 & 16 \\
\hline \multicolumn{2}{|c|}{ Total } & 33 & 100 \\
\hline
\end{tabular}

The table 1 shows that most of the respondents have good knowledge of 19 people (57\%). Knowledge is a predisposing factor in addition to attitudes and education. The enabling factor is the availability of masks and a reinforcing factor where there are regulations and supervision from the government regarding the use of masks.[6] Even though the predisposing factor is good while the other two factors are lacking or even not, it will cause an incomplete health behavior while the health behavior will be directly related to lung function disorders.

\subsection{Respondents' Attitudes about the Wearing a Masks}

Table 2. Distribution of Respondents' Attitudes about the Wearing a Masks

\begin{tabular}{|l|c|c|c|}
\hline No & Attitude & f & \% \\
\hline 1 & Positive & 23 & 70 \\
2 & Negative & 10 & 30 \\
\hline \multicolumn{2}{|c|}{ Total } & 33 & 100 \\
\hline
\end{tabular}

Table 2 shows that most of the respondents have a positive attitude as many as 23 people (70\%). Attitude is an expression of the values possessed by a person. Attitudes can be formed so that the desired behavior occurs. Attitudes cannot be directly seen, but can only be interpreted beforehand from closed behavior, not an open reaction or open behavior. Attitude is a readiness or willingness to act, not an implementation or action. Attitudes affect the experience of an individual that comes from the urge in the heart, habits and influences from the environment around the individual. [7] The factors that influence the formation of attitudes are: (1) Personal experience, 2) Other people, (3) Culture, (4) Mass media, (5) Educational and religious institutions, and (6) Emotional factors. [5]

The high attitude of mothers in giving masks to children is due to several factors, namely: technological developments at this time, so that access to health is very easy. Many media about health that are witnessed or accessed by mothers make mothers easily influenced by these advertisements or broadcasts. 


\subsection{Respondents' Behavior regarding the Wearing a Masks}

Table 3. Distribution of Respondents' Behavior regarding the Wearing a Masks

\begin{tabular}{|l|l|c|c|}
\hline No & $\begin{array}{c}\text { Use of Masks on } \\
\text { Children }\end{array}$ & $\mathbf{f}$ & \% \\
\hline 1 & Done & 25 & 76 \\
2 & Not Done & 8 & 24 \\
\hline \multicolumn{2}{|c|}{ Total } & 33 & 100 \\
\hline
\end{tabular}

Table 3 shows that most of the respondents have the behavior of using masks in children as many as 25 people (76\%). Behavior is a function of the interaction between an individual and his environment, which means that both directly determine behavior. Behavior has three components, namely knowledge, attitude, and action. A person's behavior is determined by many factors therefore it is necessary to conduct careful research regarding which factors are dominant in influencing the behavior [8]

Based on the results of the Spearman Rho statistical test at a significant level of $p=0.05$ with the number of respondents 33 people, the Asymp. sig value of $0.000<$ (0.05) was accepted, which means that there is a relationship between knowledge and attitude with the mother's behavior in wearing masks to children in Meri, Mojokerto City.

\section{DISCUSSION}

Knowledge is the ability of a person to understand something after interacting with his environment. This ability is also influenced by educational factors. This is in line with the results of research conducted regarding the role of education in shaping behavior, that is, all respondents have attended formal education levels ranging from junior high school, high school to university level. [5]

Education is a process of delivering materials or materials carried out by educators to education to achieve behavior change. Someone with a high formal educational background will have a high level of knowledge and reasoning as well as diverse perceptions related to something compared to someone with a low formal education background education.[9] In addition, education can also affect a person's way of thinking at work. Based on the education level of the respondents, the lowest education level of the respondents is elementary school, while the average education level of the respondents is high school. With the level of education that the respondent has passed, it will contribute to the proportion of good knowledge about preventive behavior because through the educational process a person will learn various disciplines so that someone will gain broad knowledge. This situation is caused by the higher the level of education, the higher the ability to absorb knowledge or information. [7]
The mother's behavior in using masks in children is determined by the mother's knowledge about the benefits of using masks. Information absorbed by mothers regarding the use of masks to prevent transmission of the corona virus will indirectly increase mother's knowledge, and increase mother's knowledge which leads to increased maternal behavior in using masks in children.[4]

Attitude is a reaction or response of someone who is still closed to a stimulus or object. Attitudes clearly show the connotation of a suitability of reactions to certain stimuli. Attitude is not yet an action or activity, but is a predisposition to action or behavior. Attitude measurement is done directly and indirectly. You can directly ask how the respondent's opinion or question is about an object. Indirectly it can be done with hypothetical statements, then the respondent's opinion is asked. (strongly agree, agree, disagree, strongly disagree [6]

Attitude refers more to readiness and willingness to act, and not the implementation of certain motives. This is because many factors influence the formation of attitudes and the formation of this attitude is what makes workers have negative and positive attitudes. To realize an attitude into a real action, a supporting factor or an enabling condition is needed, including facilities. In addition, support factors from other parties are also needed, for example from family, friends, or other fellow workers. Attitudes that exist in a person will be influenced by internal factors, namely physiological and psychological factors, as well as external factors. External factors can be in the form of situations faced by individuals, norms and obstacles that exist in society, all of which will affect the attitude that exists in a person.

\section{CONCLUSION}

This study found that there was a relationship between maternal knowledge and attitude with the behavior of using masks in children in efforts to prevent COVID-19. The information that is absorbed by mothers regarding the use of masks to prevent direct transmission of the coronavirus will increase the knowledge and attitudes of mothers, and the increasing knowledge and attitudes of mothers will increase the behavior of mothers in using masks to children.

\section{AUTHORS' CONTRIBUTIONS}

AMY: concept and design, writing, DHS: concept and design, writing, MHS: data analysis, writing, editing RFH: writing, editing

\section{ACKNOWLEDGMENTS}

The authors would like to gratitude STIKes Majapahit, Mojokerto that given support to this study. 


\section{REFERENCES}

[1] P. Mo et al., "Clinical characteristics of refractory COVID-19 pneumonia in Wuhan, China," Clin. Infect. Dis., 2020, doi: 10.1093/cid/ciaa270.

[2] A. Rauf et al., "COVID-19 Pandemic: Epidemiology , Etiology , Conventional and Non-Conventional Therapies," Int. J. Environ. Res. Public Health, vol. 17, no. 21, 2020.

[3] M. S. Islam et al., "Current knowledge of COVID-19 and infection prevention and control strategies in healthcare settings: A global analysis," Infect. Control Hosp. Epidemiol., vol. 41, no. 10, pp. 1196-1206, 2020, doi: 10.1017/ice.2020.237.

[4] T. Toharudin, R. S. Pontoh, S. Zahroh, A. Akbar, and N. Sunengsih, "Impact of large scale social restriction on the COVID-19 cases in East Java," Commun. Math. Biol. Neurosci., vol. 2020, pp. 1-19, 2020, doi: $10.28919 / \mathrm{cmbn} / 4837$.

[5] R. Sulistyawati, Sulistyawati; Rokhmayanti, B. Aji, S. P. M. Wijayanti, S. K. W. Hastuti, T. W. Sukesi, and M. S. Asti, "Knowledge , Attitudes, Practices and Information Needs During the COVID-19 Pandemic in Indonesia," Risk Manag. Healthc. Policy, vol. 14, pp. 163-175, 2021.

[6] D. Aldila, M. Z. Ndii, and B. M. Samiadji, "Optimal control on COVID-19 eradication program in Indonesia under the effect of community awareness," Math. Biosci. Eng., vol. 17, no. 6, pp. 6355-6389, 2020, doi: $10.3934 / \mathrm{mbe} .2020335$.

[7] B. Yanti et al., "COMMUNITY KNOWLEDGE , ATTITUDES , AND BEHAVIOR TOWARDS SOCIAL DISTANCING POLICY AS A MEANS OF PREVENTING TRANSMISSION OF COVID-19 IN INDONESIA," J. Adm. Kesehat. Indones., vol. 8, no. 1, p. 4, 2020, doi: 10.20473/jaki.v8i2.2020.4-14.

[8] N. M. Nasir, B. Baequni, and M. I. Nurmansyah, "Misinformation Related To Covid-19 in Indonesia," J. Adm. Kesehat. Indones., vol. 8, no. 2, p. 51, 2020, doi: 10.20473/jaki.v8i2.2020.51-59.

[9] R. R. Aliyyah et al., "The Perceptions of Primary School Teachers of Online Learning during the COVID-19 Pandemic Period: A Case Study in Indonesia," J. Ethn. Cult. Stud., vol. 7, no. 2, pp. 90-109, 2020. 